IKONOMIKA: Jurnal Ekonomi dan Bisnis Islam

Volume 3, No 2 (2018)

ISSN : 2527-3434 (PRINT) - ISSN: 2527-5I43 (ONLINE)

Page : I2I - I26

\title{
The Role Of Islamic Banks In Yemen In Supporting Microfinance Institutions
}

\author{
Abobakr Ramadhan Salem Al-Harethi \\ Hadhramount University, Yemen \\ abobakralharethi@gmail.com
}

\begin{abstract}
Islamic banks become the best solution to the crisis of the global financial system at present.in addition, it become also a real player in dealing with economic crises and the financial complexities of the traditional banking system prevailing in the world today. moreover, countries and governments in both developed and developing countries have become increasingly interested in the issue of microfinance because of their close association with the development in various countries and may be interested in supporting countries and governments for microfinance by enacting the necessary laws and legislation. And the establishment of institutions and bodies specialized in financing and support these microfinance in addition to the microfinance in many developed countries have become a specialty taught in universities and specialized institutes. Scientific seminars and conferences are held in order to support and develop it so that it achieves the objectives set for it and thus meets the aspirations of society in development. This study focus on the role of Islamic banks that can play an active and influential role in generating wealth and reducing poverty through financing for Microfinance institutions where the study showed the social role of the nature of contracts in Islamic banks through which Islamic banks can be the best in Microfinance.
\end{abstract}

Keywords : Islamic banks, Microfinance institutions, Yemen

\section{A. INTRODUCTION}

The subject of financing Microfinance institutionsin Islam derives its place first and foremost from the principles and mission of true Islam, which ordered the attention of the Muslim individual as a fundamental pillar in the development 
process in various fields, which requires the liberation of this individual from all forms of dependency and creating the appropriate environment for him to develop his skills and energies Innovations until the real development process moves forward (Farhan, 20I2).

The recent global financial crisis 2007-2009 has fostered debate on effective risk management and appropriate rescue policies for stable and adaptable financial systems (BCBS, 20II). Even though the ongoing debate over how best to regulate financial institutions. Regrettably, the policies set by international regulatory bodies, such as the Bank for International Settlements and the Financial Stability Board, were primarily designed for banks, and less attention was paid to microfinance. Institutions (MFIs) (Hessou, Lensink, Soumare, \& Tchuigoua, (2018). MFIs are significant financial intermediaries in the financial system of least developed countries (LDCs) and emerging economies (Reed,20I5). Islamic Banks is a financial and social institution whose objectives, principles and practices must be in line with the provisions of the Islamic Shariah (Ahmad, 2004). However, it should be noted here that the desire to abolish fixed interest rates and the Islamization of financial systems was discussed as a central theme at the first meeting of the Islamic Organization Conference in Jeddah in 1973 (Haqiqi and Pomeranz, 2005), Islamic banks were established under profit and loss system (PLS).

Islamic banks have received considerable attention from many Islamic and non-Islamic countries that have enacted their own laws to operate within the framework of constitutional legitimacy that has become part of domestic and international economic activities that the entire universe cannot rule out its positive contribution to the global economy. In addition, Islamic banks in Yemen have achieved mixed success in Yemen. The four Islamic banks and new micro-banks created under Islamic law, issued in 1996 to allow Islamic banks to operate in the country. Islamic banks are now an essential part of the banking system, which has more than $40 \%$ of the domestic market share. It provides a full range of comprehensive and integrated banking services for individuals and companies in accordance with Islamic Shariah principles (Muneer, 2018).

\section{B. THEORITICAL}

\section{Islamic Banks In Yemen}

It took more than 16 years to prepare for the Islamic banks of Yemen to start operations before they became reality in 1996. While various economic indicators have confirmed that Yemen suffered a severe economic crisis in the early 
I990s, forcing Yemen to adopt an economic reform program recommended Including the World Bank and the International Monetary Fund, which also recommended the establishment of Islamic banks. Therefore, the government rushed to issue a decree to Islamic banks in I996. So, the Islamic Bank of Yemen Investment and Finance was the first Islamic bank to obtain this license, and thus three Islamic banks were licensed such as Saba Islamic Bank and Tadhamon Islamic Bank and Yemen Bahrain Shamel Bank. In 2009, conventional banks were authorized to open Islamic self-regulatory branches, a giant step towards the success of Islamic finance. (Farhan, 2012).

The Islamic Bank of Yemen stressed that the Islamic banks have a weak awareness of Islamic law, stressing that the Central Bank of Yemen should deal with Islamic banks, but taking into account the specificities that can be seen in two things:

I. Establish a special monitoring unit to monitor Islamic banking activities.

2. All systems and tools must be in line with the specificity of the activities of Islamic banks.

\section{Microfinance Institutions}

MFIs often provide short-term loans to borrowers. Both the duration of the loan and the repayment period are usually short. In addition, MFIs require frequent payments of loans, such as weekly payments. This is done by providing weekly repayments, so MFIs are able to reduce the premium amount for loans. This helps the smaller instalment borrowers to repay their loans because the repayment amount is low. However, microfinance institutions that adopt this lending practice impose higher interest rates, especially between those that intend to be financially independent and those that do not wish to rely on subsidies or contributions (Liman, Hashim \& Arshad, 2017)

MFIs are those institutions that mostly focus on targeting poor people in different parts of the world, particularly in developing countries. Yemen is one of the poorest developing Arab countries in the world, especially in the Middle East and North Africa region, which suffers from many developmental problems.Since the establishment of the Microfinance concept in Yemen in 1998, the government has continued to support the microfinance sector there but badly by establishing the bodies required to support it financially and technically (Alshebami \& Rengarajan, 2017).In addition, The Yemeni government has taken a major step to strengthen the country's small and medium-sized enterprises and microfinance sectors so that poverty can be somewhat alleviated and new jobs created by helping MFIs operating there. 


\section{METHODOLOGY}

The study has an exploratory descriptive approach aimed at describing the role of Islamic banks in financing and studying microfinance and exploring the obstacles facing financing and trying to overcome them by offering proposals to Islamic banks to play their role in supporting microfinance. The sources of the study were that they followed the descriptive approach, but relied in their sources on books, scientific journals, research conferences, seminars and the Internet.

\section{RESULS AND DISCUSSION}

The results of these studies have shown that the following are the main findings of this study during the period of preparation:

First: The sector of Microfinance is considered to be very important in achieving the development process in various areas of society, because of the importance of the sector as a basis for the process of comprehensive development.

Second, the Microfinance sector, despite its importance in the Arab countries, does not meet the desired level, which is commensurate with the importance of the Microfinance sector and its prominent role in the development process.

Third, there is a large and clear difference between Islamic finance as a result of the rules of Islamic religion and financing.

Fourth: Islamic finance with its characteristics, features and forms reflects Islam's insight as the religion of Allah and its law, which is entrusted to all its creation in order to achieve the real and comprehensive development process based on the consideration of the characteristics and the individual's constituents as the basis of the universe and thus the basis of the development process.

\section{E. CONCLUSION}

Islamic banks have become the best solution to the crisis of the global financial system at present. It has also become a real player in dealing with the economic crises and financial complexities of the traditional banking system prevailing in the world today. In addition, countries and governments in both developed and developing countries are increasingly interested in the issue of microfinance because of their close association with development in different countries and may be interested in supporting countries and governments for microfinance by enacting the necessary laws and legislation. Islamic banks in Yemen and their role in the financing of micro-enterprises as Islamic banks play an active and influential role in generating wealth and reducing poverty through funding of microfinance institutions where the study showed the social role of the nature of contracts in 
Islamic banks through which Islamic banks to be better in microfinance. But there is still twice as much in the role of these banks towards microenterprise support, so we recommend that microfinance received attention in the future by Islamic banks.

Recommendations: The importance of giving the State great attention to the subject of naming the sector of Microfinance because of the importance of this issue in achieving the development process that the State seeks to achieve where the state must have a comprehensive strategy aimed at improving this sector and upgrading it to ensure a cycle in the development process and support the state.We also recommend Islamic banks to have a comprehensive development strategy to support and develop the Microfinance sector, focusing on their strategy to encourage the owners of innovations, skills and innovations to develop their ideas and improve their skills by transforming these skills and innovations into organized projects benefiting the individual, the Islamic bank and society. It should focus on development projects for youth, university graduates and women's development projects. We also recommend that Islamic banks work hard to study new financing formulas that are more effective and more capable of balancing the characteristics of Microfinance. These new formulas should take into consideration the different fields and specialties of Microfinance, making them more capable of translating the interests of the bank and the small business. We also recommend that banks and Islamic institutions have an effective financing strategy to finance the small business sector. It is necessary to attract as many investors as possible by defining the role of such banks and Islamic financial institutions and the potential advantages they can derive from Islamic financing, and thus channelling these savings into the microfinance sector.

\section{REFERENCES}

Ahmed, M. (2004), "Islamic Versus Traditional Banking in Arab Region: Premises and Promises", paper presented to the International Seminar on "The Prospects of Arab Economic Cooperation”, Alexandria, Egypt.

Alshebami, A. S., \& Rengarajan, V. (2017). Microfinance Institutions in Yemen "Hurdles and Remedies". International Journal of Social Work, 4(I), I0.

Haqiqi, A. W. and Pomeranz, F. (2005), "Accounting Needs of Islamic Banking”, on line available at htt://islamic-finance.net/Islamic ethics/artcileI2.html, retrieved on $\mathrm{I0} / \mathrm{I} 6 / 2005$. 
The Role Of Islamic Banks In Yemen In Supporting

Microfinance Institutions

(Abobakr Ramadhan Salem Al_Harethi)

Hessou, H. T., Lensink, R., Soumaré, I., \& Tchuigoua, H. T. (2018). Provisioning and business cycle: Evidence from microfinance

institutions.http://www.fmaconferences.org/Norway/Papers/Conferencev ersion.pdf

Liman, N., Hashim, M. K., \& Arshad, D. (2017). A Study on the Types of Microfinance Institutions in Nigeria. MA YFEB Journal of Business and Management, 2.http://mayfeb.com/OJS/index.php/BUS/article/view/26 $\underline{3}$

Purnamasari, F., \& Darmawan, A. (2017). Islamic Banking and Empowerment of Small Medium Enterprise. Etikonomi, I6(2), 22I-230.

Reed, L.H. (20I5). Mapping Pathways out of Poverty. The State of the Microcredit Summit Campaign Report

20I5.http://www.fmaconferences.org/Norway/Papers/Conferenceversion. pdf 